\title{
NEW DESIGN APPROACH FOR DRAINS COVERINGS
}

\author{
Walaa Y. El-Nashar ${ }^{1}$, Magdy H. Mowfy ${ }^{2}$ \\ ${ }^{1,2}$ Water Engineering and Water Structure Engineering Department, Faculty of Engineering, Zagazig University, \\ Zagazig, El-Sharkia, Egypt
}

\begin{abstract}
Drain covering is the most widely used option to try to mitigate the environmental problems that arise around the drains. The main problems which lead to a perceived need to cover a drain are: to minimize the adverse impact of a polluted drain, especially close to residential areas; need to use the land area occupied by the drain for an access road or some other use and poor soil stability leading to bank failure. The drain covering cross section can take several forms such as box section (square or rectangular) or concrete pipes. In this paper a new approach is suggested for covering. This approach is constructing as a bridge which consists of two abutments from brick on plain concrete footing and reinforced concrete slab. There are holes at certain distance to carry out maintenance works. Its parts are designed according to different live load cases and for spans 1-5m. Design curves are designed for the new approach of covering in Egypt area. Design curves include design of each part of the new approach. This approach is applied for a drain which is covered as a pipe type and another drain which is covered as box type. The hydraulic and economic study is done for this approach. Head losses are calculated for pipe, box types and for the new approach. It is found that the head losses for the new approach is less than pipe type by $98 \%$ and less than box type by $97.8 \%$. The cost of pipe, box types and for the new approach is calculated. It is found that the cost of the new approach is more than pipe type by $49 \%$ and more than box type by $27 \%$.
\end{abstract}

Keywords: Drain Covering; New Approach for Covering; Design Charts; head losses and Egypt.

\section{INTRODUCTION}

The covering is closed canal or industrial type. Covering is created to pass the discharge of waterway under the road or railway line. Mainly used to pass the small discharge to function as bridge, there are two types for covering is pipe or box type. The protection of agricultural drains against pollution resulting from illegal dumping of both liquid and solid waste in residential areas can be achieved in different ways. The positive impact of covering: protects the drain from dumping of solid and liquid wastes by moving it and away from the source of the wastes. The negative impact: high cost, difficulty of finding an alternative route and encroachment of residential areas to the new drain sites as a result of population growth. There are a lot of researches about this topic such as Christodoulou G. [1] studied the losses at drop manholes in supercritical pipelines. He found that the local head-loss coefficient is governed by a dimensional drop parameter, expressed in terms of the drop height and the inflow velocity. Ferro V. [2] reported the results of an investigation carried out to test the applicability of the selfsimilarity hypothesis for determining the flow-resistance law in small-diameter plastic pipes. Hager and Guidice [3] derived dimensionless equations of culvert flows for basic flow types: critical, uniform, gated, and pressurized flows. Bombardelli F. and Garcia M. [4] used the Hazen-Williams formula for the design of large-diameter pipes, without regard for its limited range of applicability. Brasington J. and Smart R. [5] investigated the evolution and dynamics of larger-scale landforms. Lee and Jin [6] developed a computer program for the design of rectangular culverts, which needs a number of iterations for achieving a solution. Wood D. [7] studied the traditional approach to transient analysis might dispute the claim. Ku and Jun [8] made a computer program that considers non-uniform characteristics of the flow in the culvert by widely adopting new information. Kang et al [9] recommended the concept of critical storm duration be appropriate to estimate a design flood discharge for culvert design. Korea Expressway Corporation [10] described similar hydraulic design procedures for culverts. Fahmy M. [11] studied the covering of canals and drains, advantages and disadvantages; she evaluated the hydraulic side and the economic side. Vatankhah A. and Easa S. [12] used the Manning formula and the attractive force equation as governing equations to design erodible and riprap channels. Colin, Catherine and Fabre [13] experimented on vertical turbulent flow with mill metric bubbles, under three gravity conditions, upward, downward and microgravity flows. Yoo D. and Lee S. [14] determined dimensions of a rectangular culvert section, current design approaches by using several trial calculations. Catherine and Fabre [15] experimented on vertical turbulent flow with mill metric bubbles, under three gravity conditions, upward, downward and microgravity flows. Dong-Hoon Y. and Sangho L. [16] determined dimensions of a rectangular culvert section, current design approaches by using several trial calculations. Park et al [17] investigated the behavior of concrete pavement according to the cover depth of the box culvert at the length of the 
reinforced slab. Babajimopoulos C. and Terzidis G. [18] determined the diameter of pipe flow problems which required the use of diagrams or iterative solutions of the Colebrook white equation.

The main objective of this study is invention a new approach for covering the drains and introducing the design charts for the new approach of covering.

\subsection{Selection Criteria for Drain Covering}

The key selection criteria are:

1. Location;

2. Water quality in the drain;

3. Drain dimensions;

4. Flow rate;

5. Population;

6. Cost;

7. Maintenance;

8. Proposed use of the land;

9. Social factors;

10. Expected use of the water in the drain; and

11. Environmental practices in the area by its residents.

\subsection{Drain Covering Options}

Drain covering is the most widely used option to try to mitigate the environmental problems that arise around the drains. The drain covering cross section can take several forms such as:

i- Box Type: In this type, the cross section of the vent can be rectangular or square and can have one or more vents.

ii- Pipe Type: This type, which can have one or more barrels, is more suitable for waterways with a small discharge. The pipes should be constructed from pre-cast reinforced concrete. The length of the pre-cast units will depend on the pipe diameter and the specification of the reinforcement used.

\subsection{Negative Impacts of the Covering}

1- High cost;

2- Encroachment of residential areas to the new drain sites as a result of population growth;

3- It will not reduce dumping of liquid and solid wastes in the streets of the residential areas.

4- It will not prevent dumping of solid wastes around the fences;

5- It will not prevent discharge of solid wastes from above or through the fencing, unless a very high fence is used;

6- It will not prevent discharge of human wastes through illegal connections;

7- It is very difficult to gain access to maintain the banks of the drain mechanically and it needs regular painting and repair;

8- It does not control unpleasant odors or breeding of insects;
9- Prevent the end reaches of canals from receiving the irrigation water;

10- Cause pollution in irrigation and municipal water due to drainage solids and liquids waste in the covering;

11- Cause death to worker during maintenance;

12- Increase of sedimentation through covering and in upstream for covering;

13-Rising the water table in the agricultural area due to silting in manhole and cross-section of pipe or box section; and

14- The difficulty of maintenance with small cross-section.

\section{METHODOLOGY}

The methodology of this paper includes:

1-Invent a new approach for covering the drains;

2- Design of the different parts of this new approach;

3 - Introduce the design charts for the different parts design of this new approach;

4- Application of this new approach on a drain which is covered by pipe section and another drain which is covered by box section; and

5- Compare between the new approach and actual covering in hydraulic and economic points.

\section{THE COMPONENTS OF THE NEW}

\section{APPROACH}

This approach is consists of two abutments from brick on plain concrete footing and reinforced concrete slab. There are holes at certain distance to carry out maintenance works as shown in Fig-1.

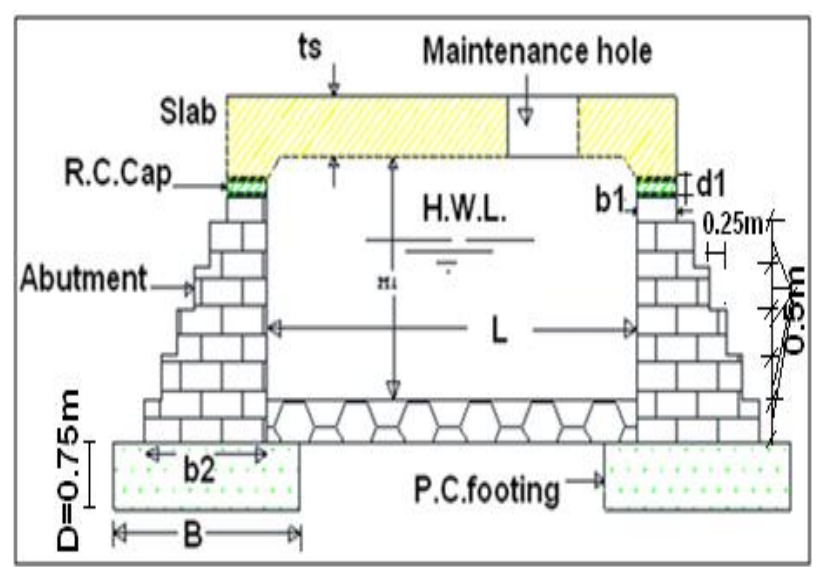

Fig-1: Suggested New Approach for Covering

\subsection{Structural Design}

The structural design includes the following:

1- Design of the slab;

2- Design of cap; and

3- Design of abutment. 


\subsubsection{Slab Design}

To design the slab, dead load and live load are calculated as following:

\subsubsection{Dead Load}

$$
\mathrm{W}_{\mathrm{DL}}=\gamma_{\mathrm{R} . \mathrm{C}} * \mathrm{t}_{\mathrm{S}}+\gamma_{\text {asp }} * \mathrm{t}_{\mathrm{asp}}[19]
$$

Where;

$\mathrm{W}_{\mathrm{DL}}$ : Dead load weight $\left(\mathrm{t} / \mathrm{m}^{2}\right)$;

$\gamma_{\text {R.C }}$ : Density of reinforced concrete $\left(\mathrm{t} / \mathrm{m}^{2}\right)$;

$\mathrm{t}_{\mathrm{s}}$ : Slab thickness $(\mathrm{m})$;

$\gamma_{\text {asp }}$ : Density of asphalt $\left(\mathrm{t} / \mathrm{m}^{2}\right)$; and

$\mathrm{t}_{\mathrm{asp}}$ : Asphalt thickness (m).

$$
M_{D L}=\frac{W_{D L} * L_{e f f}^{2}}{8}[19]
$$

Where;

$M_{D L}$ : Moment of dead load $\left(\mathrm{t} / \mathrm{m}^{2}\right)$;

$L_{\text {eff: }}$ : Effective length $=0.15^{*} \mathrm{~S}$; and

$\mathrm{S}$ : Span of the drain (m).

\subsubsection{Live Load}

Live load is from the wheels of (20,30, 60 and 70 tons) lorry as shown in Fig-2.

$$
I=\frac{P_{1} * 20 \%}{A * B}[19]
$$

Where;

I: Impact factor; $A=\mathrm{t}_{\mathrm{s}}+2 \mathrm{t}_{\mathrm{asp}}+0.6$;

$P_{1}$ : Wheel load; and $B=\mathrm{t}_{\mathrm{s}}+2 \mathrm{t}_{\mathrm{asp}}+0.2$.

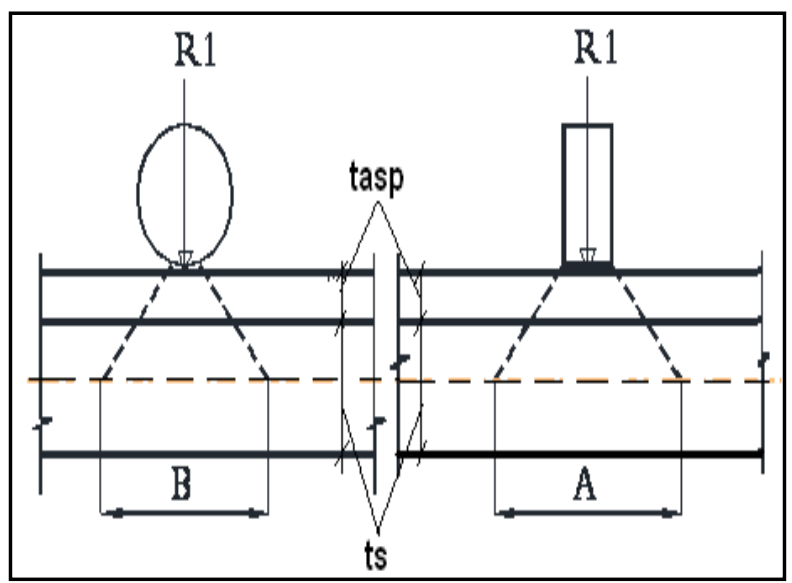

Fig-2: Live Load from the Wheel

$$
M_{L L}=\frac{R_{1} * L_{e f f}}{2}-\frac{W_{1} * B}{2} * \frac{B}{4}[19]
$$

Where;

$M_{L . L}:$ Moment of live load $\left(\mathrm{t} / \mathrm{m}^{2}\right)$;

$W_{l}$ : distribution Load; and

$R_{l}$ : the reaction of the live load; $R_{1}=\frac{W_{1} * B}{2}$

$$
\begin{aligned}
& M_{\text {total }}=M_{D L}+M_{L L} \\
& d_{t}=K_{1} \sqrt{\frac{M_{\text {total }}}{b_{t}}}[19] .
\end{aligned}
$$

Where;

$d_{t}=$ ts- cover; $\quad b_{t}=$ strip width $=100 \mathrm{~cm}$; and $K_{l}$ : Constant from the tables [19].

$$
\text { As }=\frac{M_{\text {total }}}{K_{2} * d_{t}}[19]
$$

Where;

$A_{s}:$ area of steel $\left(\mathrm{cm}^{2}\right)$; and

$K_{2}$ : Constant from the tables [19].

\subsubsection{Cap Design}

To design the cap the following questions are used:

$f_{c o n}=\frac{N_{c o n}}{A_{c s}}[19]$

$A s_{\min }=\frac{0.15}{100} * d_{1} * b_{1}[19]$

Where;

$f_{\text {con }}:$ Stress $(\mathrm{Kg})$;

$N_{\text {con }}:$ Total Reaction $=\mathrm{R}_{\mathrm{t}}=\mathrm{R}_{\mathrm{D} . \mathrm{L}}+\mathrm{R}_{\mathrm{L} . \mathrm{L}}$;

$A_{c s}:$ area at section $=\mathrm{b}_{\mathrm{t}} * 1.0 \mathrm{~m}$;

$A s_{\min }:$ (area of steel) ${ }_{\min }\left(\mathrm{cm}^{2}\right)$;

$d_{1}$ : Cap thickness $=25 \mathrm{~cm}$; and

$b_{1}$ : Cap width $(\mathrm{cm})$.

\subsubsection{Abutment Design}

\subsubsection{Empirical Dimension of Abutment}

The dimensions of the abutment are as shown in Fig 1.

$\mathrm{b}_{1}$ : Top Width;

$\mathrm{b}_{2}$ : Bottom Width;

B: Foundation Width; 
$\mathrm{D}_{1}$ : Foundation thickness;

Y: Water Level; and

$\mathrm{H}_{1}$ : Water Level +0.5 .

\subsubsection{Checks for the Abutment}

There are three main checks for the abutment as following:

\section{1- Check of Sliding}

$$
\text { F.O.S }=\frac{. \mu^{*} N}{T}>1.5(\text { safe })[19]
$$

Where;

F.O.S: Factor of Safety;

$\mu:(0.5-0.75)$;

$N: \sum$ Stability; and

$T: \sum$ over Turning.

\section{2- Check of Over Turning}

$$
\text { F.O.S }=\frac{\text { StabilityM oment }}{\text { OverTurningMoment }}>2.0(\text { safe })[19] \ldots
$$

\section{3- Check of Stress}

$$
\begin{aligned}
& F_{12}=\frac{-N}{A}\left[1 \pm 6 X * e / b_{t}\right][19] \\
& X=\frac{. M_{n e t}}{N}[19] . \\
& M_{\text {net }}=M_{\text {stability }}-M_{\text {over turning }} \text {. } \\
& e=\frac{b_{2}}{2}-X[19]
\end{aligned}
$$

Where;

$A$ : Area at section;

$b_{t}$ : Strip width $=100 \mathrm{~cm}$.

\section{THE RESULTS OF DESIGN}

The results of design include the design charts for designing of slab, cap and abutment. The design chats for slab are shown in Chart-1. The design chats for cap are shown in Chart-2. The design chats for abutment for different span of drain $(1 \mathrm{~m}, 2 \mathrm{~m}$, $3 \mathrm{~m}, 4 \mathrm{~m}$ and $5 \mathrm{~m}$ ) are shown in Chart-3.

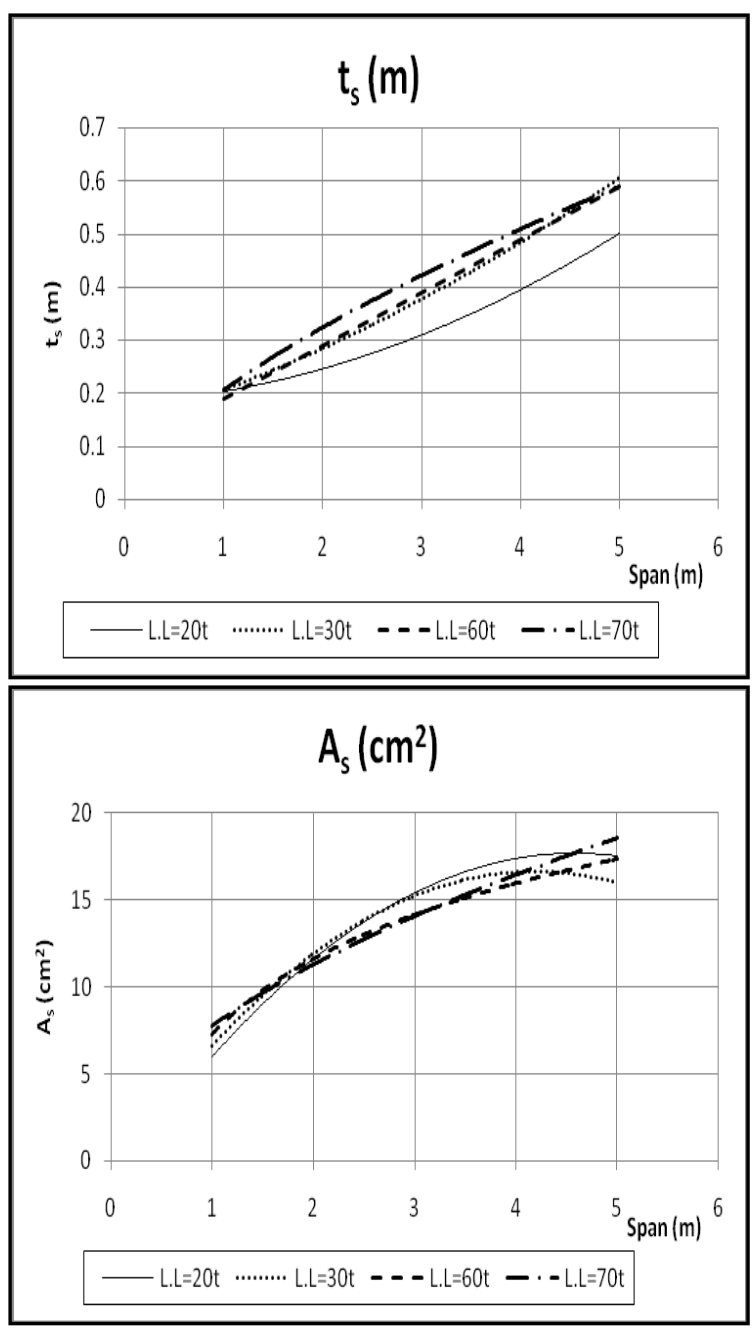

Chart-1: The Design Curves for the Slab

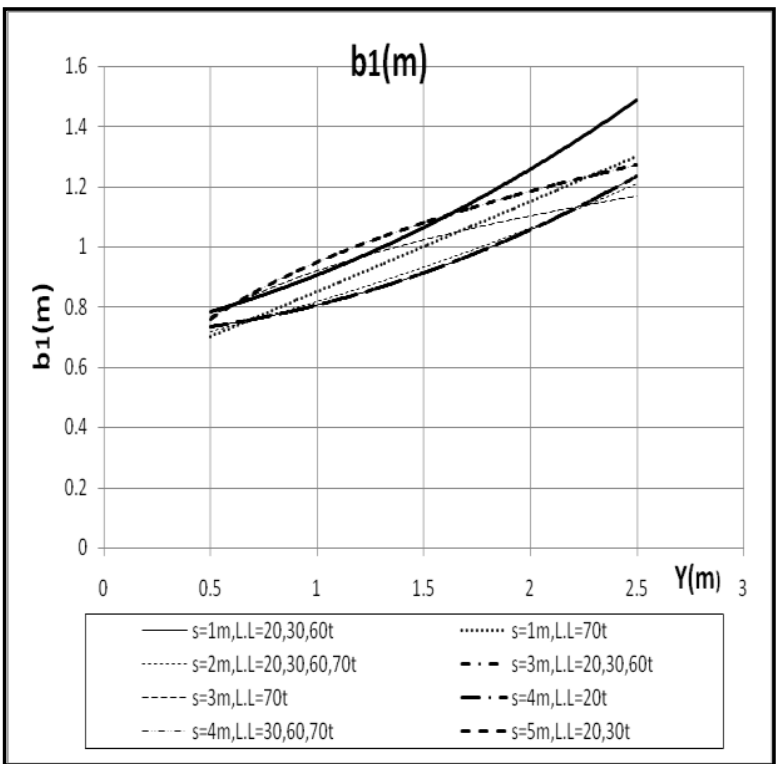




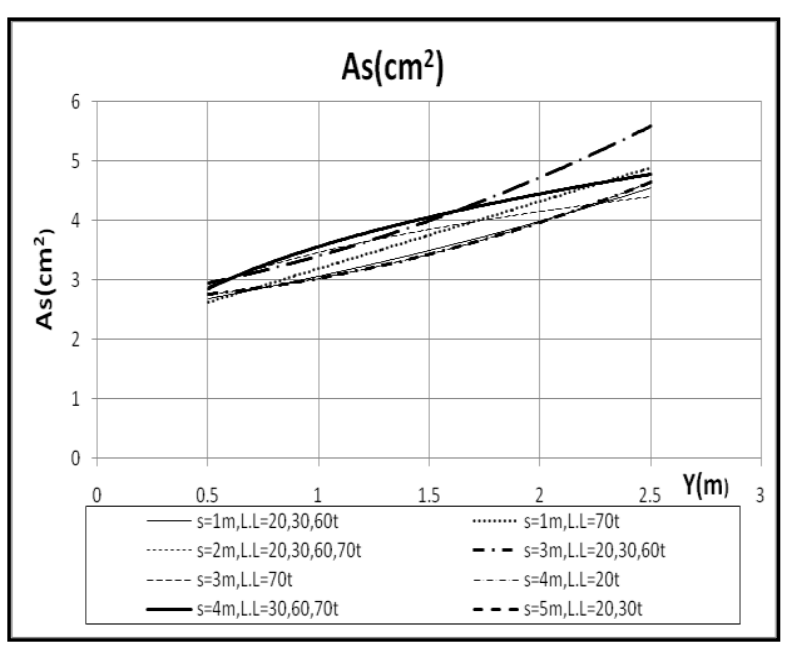

Chart-2: The Design Curves for the Cap

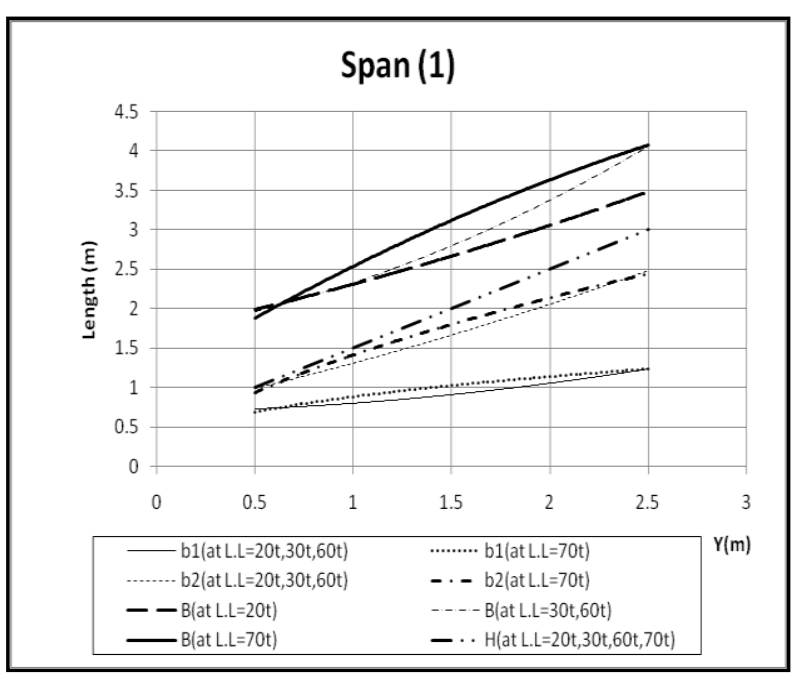

a: $\operatorname{Span}=1 \mathrm{~m}$

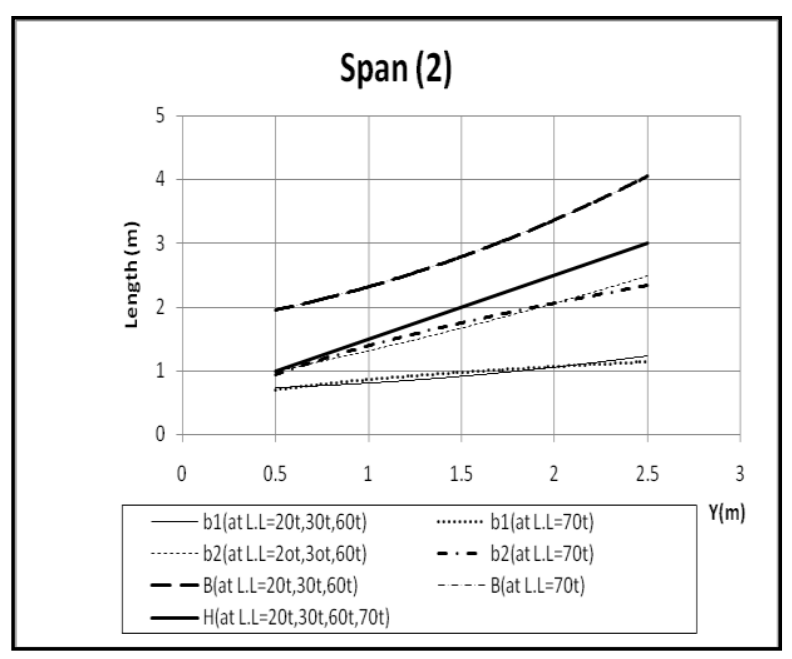

$\mathrm{b}: \mathrm{Span}=2 \mathrm{~m}$

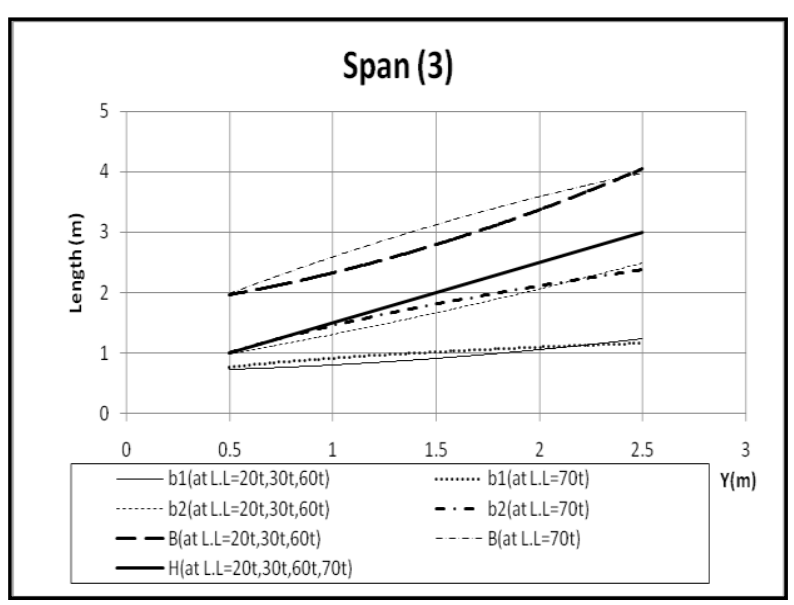

c: $\mathrm{Span}=3 \mathrm{~m}$

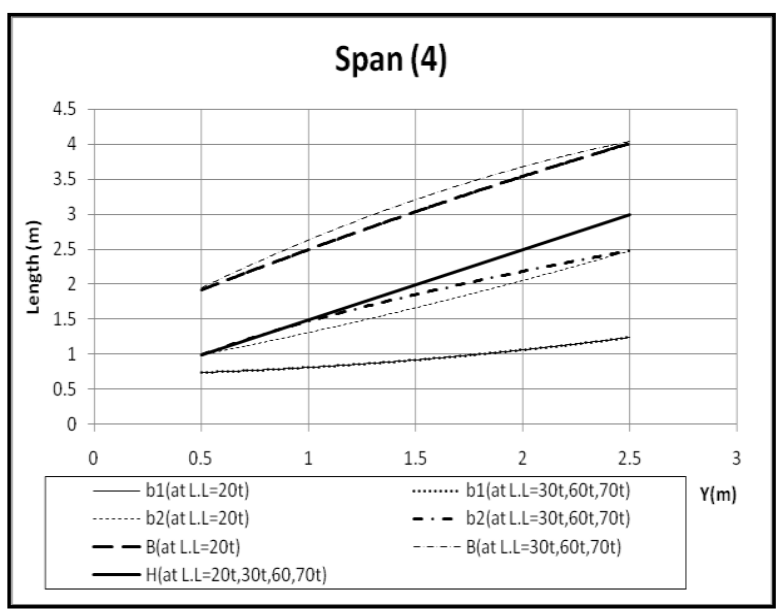

d: $S p a n=4 m$

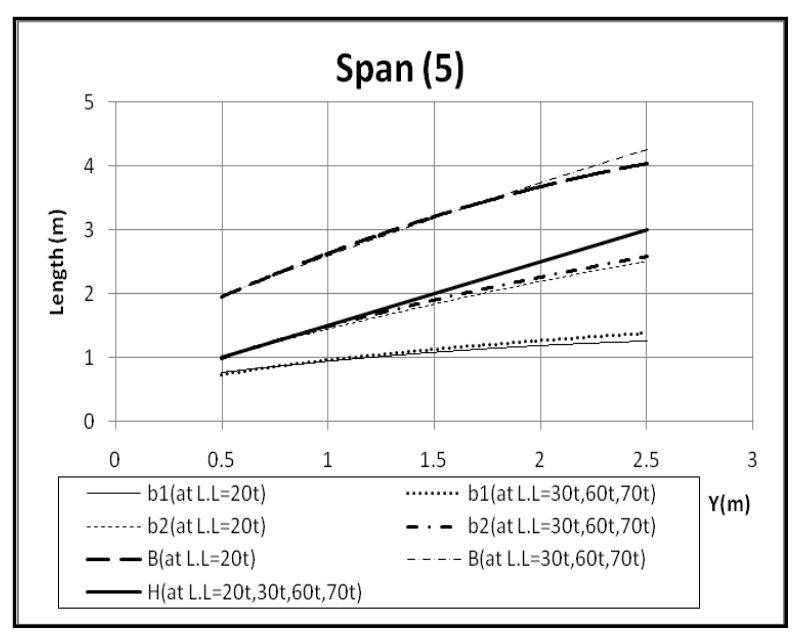

\section{e: Span $=5 \mathrm{~m}$}

Chart-3: The Design Curves of Abutment for Different Spans 


\section{APPLICATION OF THE NEW APPROACH}

This approach will be applied on two drains. One of them is covered by pipe type and another one is covered by box type.

\subsection{El-Ahras Drain}

This drain is covered by pipe type. Its span is $3.0 \mathrm{~m}$, water level is $1.5 \mathrm{~m}$ and discharge is $2.292 \mathrm{~m}^{3} / \mathrm{sec}$. By designing this drain as the new approach for critical live load (70 ton lorry), the result of this designing is shown in Fig-3. Main area steel (As) for the slab is $8 \phi 16$ and min area steel is $6 \phi 12$. Main area steel (As) for the cap is $5 \phi 12$.

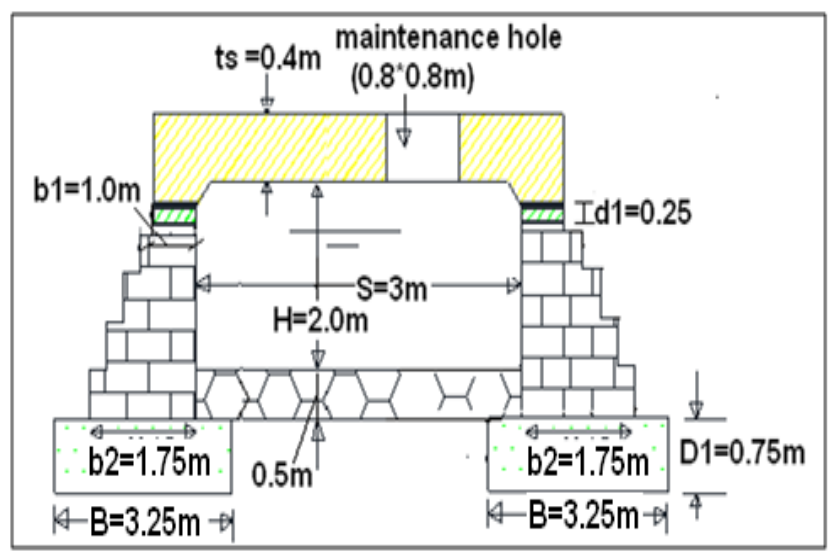

Fig-3: Suggested New Approach for El-Ahras Drain

\subsection{Natora 1 Drain}

This drain is covered by box type. Its span is $3.0 \mathrm{~m}$, water level is $1.0 \mathrm{~m}$ and discharge is $0.86 \mathrm{~m}^{3} / \mathrm{sec}$. By designing this drain as the new approach for critical live load (70 ton lorry), the result of this designing is shown in Fig-4. Main area steel (As) for the slab is $8 \phi 16$ and min area steel is $6 \phi 12$. Main area steel (As) for the cap is $4 \phi 12$.

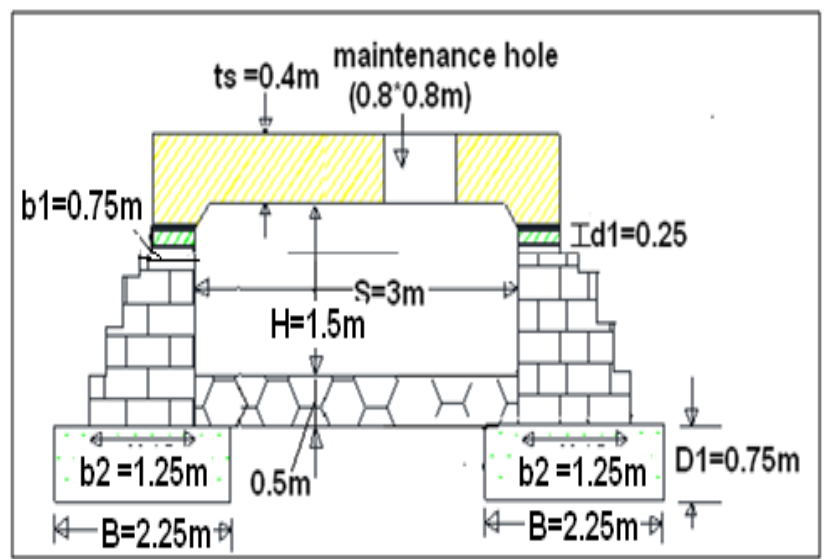

Fig-4: Suggested New Approach for Natora1 Drain

\section{THE EFFECT OF THE NEW APPROACH ON THE HEAD LOSSES (HL):}

To calculate the head losses of the new approach, the following equation [20] is used:

$$
h_{\alpha}=\alpha * \beta * \frac{V_{D}{ }^{2}}{2 g}[20]
$$

Where;

$h_{\alpha}$ : the head losses of the new approach $\alpha$ : is the contraction coefficient $=\left(A_{D}-a\right) / A_{D}$

$A_{D}$ : area of drain cross section $\left(\mathrm{m}^{2}\right)$;

a: area trough the new approach $\left(\mathrm{m}^{2}\right)=\mathrm{S}^{*} \mathrm{y}$;

$\beta$ : is the factor $=0.68$

$\mathrm{S}$ : span of drain (m); and

$V_{D}$ : velocity in the drain $=\mathrm{Q} / \mathrm{A}_{\mathrm{D}}$

To calculate the head losses ( $\mathrm{Hl})$ of pipe type, Darcy equation is used [21]:

$$
\begin{aligned}
& H l=h_{1}+h_{2} \ldots \ldots \ldots \ldots \ldots \ldots \ldots \ldots \ldots \ldots \\
& \boldsymbol{h}_{1}=\frac{4 * f * \boldsymbol{L} * \boldsymbol{V}_{p}{ }^{2}}{2 * g * \boldsymbol{D}} \\
& \boldsymbol{h}_{2}=\frac{\boldsymbol{V}_{p}{ }^{2}}{2 * g} \ldots \ldots \ldots \ldots \ldots
\end{aligned}
$$

Where,

$H l$ : Total heading up $(\mathrm{m})$;

$h_{1}$ : Head losses from friction due to full flow (m);

$h_{2}$ : Head losses from velocity (m);

$f$ : Friction factor (dimensionless);

$L$ : Length of covering (m);

$V_{p}$ : Velocity of the flow through the pipe $(\mathrm{m} / \mathrm{sec})$; and $g$ : Gravity acceleration $\left(\mathrm{m} / \mathrm{sec}^{2}\right)$.

To calculate the heading up for box type $\left(H_{l b o x}\right)$, the following equation is used:

$$
H_{l b o x}=h_{f}+h_{e n}[22] . .
$$

Where,

$h_{f}$ : Losses due to friction (m);

$h_{e n}$ : Losses due to entrance (m);

$$
\begin{aligned}
& h_{f}=L\left(\frac{Q * n}{1.486 * A * R^{2 / 3}}\right)^{2} \\
& h_{e n}=K_{e n} \frac{V_{e n}^{2}}{2 g}[22] \ldots \ldots \ldots \ldots \ldots
\end{aligned}
$$


Where,

$n$ : Coefficient of roughness (dimensionless);

$R$ : Hydraulic radius (m);

$K_{e n}$ : Entrance losses coefficient (dimensionless); and

$V_{e n}:$ Entrance velocity $(\mathrm{m} / \mathrm{sec})$.

The head losses of El-Ahras drain by pipe type and new approach and the head losses of Natoraldrain by box type and new approach are shown in Table-1.

Table-1: Head Losses of El-Ahras and Natora 1 Drains

\begin{tabular}{|c|c|c|c|}
\hline \multicolumn{2}{|c|}{ El-Ahras Drain } & \multicolumn{2}{c|}{ Natora1 Drain } \\
\hline $\begin{array}{c}\text { Pipe } \\
\text { Type }\end{array}$ & $\begin{array}{c}\text { New } \\
\text { Approach }\end{array}$ & $\begin{array}{c}\text { Box } \\
\text { Type }\end{array}$ & $\begin{array}{c}\text { New } \\
\text { Approach }\end{array}$ \\
\hline $0.1 \mathrm{~m}$ & $0.002 \mathrm{~m}$ & $0.08 \mathrm{~m}$ & $0.0017 \mathrm{~m}$ \\
\hline
\end{tabular}

\section{ECONOMY STUDY}

The cost per meter length of the covering will be the most important selection criteria. The cost of pipes, box section, and section of new approach for the two cases is calculated as shown in Table-2.

Table-2: Cost of El-Ahras and Natora 1 Drains

\begin{tabular}{|c|c|c|c|}
\hline \multicolumn{2}{|c|}{ El-Ahras Drain } & \multicolumn{2}{c|}{ Natora1 Drain } \\
\hline $\begin{array}{c}\text { Pipe } \\
\text { Type }\end{array}$ & $\begin{array}{c}\text { New } \\
\text { Approach }\end{array}$ & $\begin{array}{c}\text { Box } \\
\text { Type }\end{array}$ & $\begin{array}{c}\text { New } \\
\text { Approach }\end{array}$ \\
\hline 2370L.E & 4680L.E. & 3410 L.E & 4680L.E. \\
\hline
\end{tabular}

From the previous tables, we find that suggested new approach design of covering is the largest price when compared with other covering types but there are many benefits of the new approach as following:

1- Easy construction;

2- Minimum head losses;

3- Minimum contraction;

4- No sediment in bed;

5- No grasses grow; and

6- Easy mantic manually and mechanical.

\section{CONCLUSION}

The options for drain covering are essentially two to use pipes or concrete box sections. But there are many negative impacts of the covering however a new approach is suggested for covering in this paper. This approach is constructing as a bridge which consists of two abutments from brick on plain concrete footing and reinforced concrete slab. There are holes at certain distance to carry out maintenance works. Its parts are designed according to different live load cases 20, 30, 60 and 70 ton lorry, for spans 1-5m. Design curves are designed for thickness and area of steel for the slab. Design curves are designed for width and area of steel for the cap. Design curves are designed for different dimension for the abutment. This approach is applied for El-Ahras drain which is covered as a pipe type and Natora1 drain which is covered as box type. The head losses of the new approach and actual covering are done. The minimum head losses are found from the new approach. . It is found that the head losses for the new approach is less than pipe type by $98 \%$ and less than box type by $97.8 \%$. The economic study is done for this approach. The cost of the new approach is higher than pipe and box type. The cost of pipe, box types and for the new approach is calculated. It is found that the cost of the new approach is more than pipe type by $49 \%$ and more than box type by $27 \%$. But there are many benefits of the new approach as: easy construction; minimum head losses; minimum contraction; no sediment in bed; no grasses grow and easy mantic manually and mechanical.

\section{REFERENCES}

[1]. Christodoulou G. "Drop Manholes in Supercritical Pipelines", Journal of Irrigation and Drainage Engineering, 1991 Vol. 117, No.1, pp. 37-47.

[2]. Ferro V. "Applying Hypothesis of Self-Similarity for Flow-Resistance Law of Small-Diameter Plastic Pipes", Journal of Irrigation and Drainage Engineering, 1997, Vol. 123.

[3]. Hager and Guidice "Generalized Culvert Design Diagram", Journal of Irrigation and Drainage Engineering, 1998, Vol. 124, No.5, pp. 271-274.

[4]. Bombardelli F. and Garcia M. "Hydraulic Design of Large-Diameter Pipes", Journal of Hydraulic Engineering, 2003, Vol. 129.

[5]. Brasington J. and Smart R. "Close Range Digital Photogrammetric Analysis of Experimental Drainage Basin Evolution", Earth Surface Processes and Landforms, 2003, Vol. 28, pp.231-247

[6]. Lee and Jin "Development of Program for Box Culverts Design", Proceedings of the $35^{\text {th }}$ Conference, Korean Society of Civil Engineers, 2003, pp. 2686-2689.

[7]. Wood D. "Water Hammer Analysis - Essential, Easy and Efficient" Journal of Environmental Engineering, 2005.

[8]. $\mathrm{Ku}$ and Jun "Development of Culvert Design Model", Proceedings of Korea Water Resources Association Conference, 2008, pp.645-649.

[9]. Kang, Koo, Chun, Her, Park and Yoo "Design of Drainage Culverts Considering Critical Storm Duration", Bios-stems Engineering, 2009, Vol. 104 No.3, pp. 425-434.

[10]. Korea Expressway Corporation "Road design guideline", 2009, Vol. 2, pp. 494-508.

[11.] Fahmy M. "Covering of Canals and Drains, Advantages and Disadvantages", Article submitted to a scientific committee of public works and water resources, 2011.

[12]. Vatankhah A. and Easa S. "Simplified Accurate Solution for Design of Erodible Trapezoidal Channels", Journal of Hydrology Engineering, 2011, Vol. 16, pp.1943-5584.

[13]. Colin, Catherine and Fabre "Turbulent Bubbly Flow in Pipe under Gravity and Microgravity Conditions" Journal of Fluid Mechanics, 2012, Vol. 711, pp. 469-515 
[14]. Yoo D. and Lee S. "Direct Determination of the Width or the Height for a Box Culvert Applying Dimensionless Equations", KSCE Journal of Civil Engineering (2012), Vol. 16, No. 7, pp.1302-1307.

[15]. Catherine and Fabre "Turbulent Bubbly Flow in Pipe under Gravity and Microgravity Conditions" Journal of Fluid Mechanics, 2012, Vol. 711, pp. 469-515.

[16]. Dong-Hoon Y. and Sangho L. "Direct Determination of the Width or the Height for a Box Culvert Applying Dimensionless Equations" KSCE Journal of Civil Engineering, 2012, Vol.16, No. 7, pp.1302-1307.

[17]. Park, Sohn, Dueck and Lee "Behavior of Jointed Concrete Pavement by Box Culvert and Reinforced Slab" Journal of the Korean Society of Road Engineers, 2012, Vol. 14 , No. 6, pp. 25-35.

[18]. Babajimopoulos C. and Terzidis G. "Accurate Explicit Equations for the Determination of Pipe Diameters" International Journal of Hydraulic Engineering, 2013, Vol. 2, No. 5, pp. 115-120.

[19]. Shaker El-Behairy "Reinforced Concrete Design Handbook" Faculty of Engineering, Ain Shames University, Fifth Edition, 1996.

[20]. Whakaora K. "Waterways, Wetlands and Drainage Guide" Part B: Design, Chapter 22, Christchurch City Council, 2003.

[21]. Satterfield "Fundamentals of Hydraulics: Flow" National Environmental Services Center, 2010, Vol. 10.

[22]. Cook, Bloomquist, Zink and Ansley "Evaluation of Precast Box Culvert Systems" Final Report No. BC354 RPWO \#47, March 2002.

\section{BIOGRAPHIES}

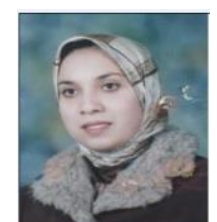

Name: Walaa Y. El-Nashar

E-mail: Walaanashar@yahoo.com.

Current Position: Lecture in Water and water Structures Engineering Department, Faculty of Engineering, Zagazig University.

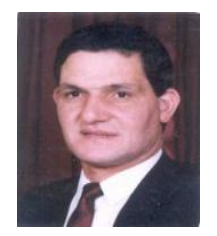

Name: Magdy H. Mowfy

E-mail: magdy_mowfy@yahoo.com.

Current Position: Professor of water structures in Water and water Structures Engineering Department, Faculty of Engineering, Zagazig University. 